\title{
THE CORRELATION BETWEEN FAT INTAKE AND PLASMA SUPEROXIDE DISMUTASE ACTIVITY WITH TELOMERE LENGTH OF MINANGKABAU ETHNICITY MEN, IN WEST SUMATERA, INDONESIA
}

\author{
AFRIWARDI AFRIWARDI ${ }^{1}$, DELMI SULASTRI ${ }^{2}$, YUNIAR LESTARI ${ }^{3}$, DESMAWATI DESMAWATI ${ }^{2}$, PRIMA MINERVA ${ }^{4}$ \\ ${ }^{1}$ Department of Physiology, Faculty of Medical, Andalas University, Padang, West Sumatera, Indonesia. ${ }^{2}$ Department of Nutrition, Faculty \\ of Medical, Andalas University, Padang, West Sumatera, Indonesia. ${ }^{3}$ Department of Public Health, Faculty of Medical, Undalas University, \\ Padang, West Sumatera, Indonesia. ${ }^{4}$ Master of Biomedical Science Program, Andalas University, Padang, West Sumatera, Indonesia. \\ Email: delmisulastri@med.unand.ac.id
}

Received: 08 September 2018, Revised and Accepted: 26 October 2018

ABSTRACT

Objective: The purpose of this research is to investigate the correlation between fat intake and plasma superoxide dismutase (SOD) enzyme activity with telomere length of Minangkabau ethnic men in West Sumatera, Indonesia.

Materials and Methods: This cross-sectional study was conducted in Padang City in 2016, using a sample of 107 Minangkabau ethnic men, aged between 40 and 50 years. The total fat, saturated fatty acids (SFA), monounsaturated fatty acid (MUFA), and polyunsaturated fatty acid (PUFA) intake were collected using a food frequency questionnaire, and blood sample analysis to measure telomere length and plasma SOD activity.

Results: This research indicated that an average telomere length was $584.59 \pm 305.92 \mathrm{bp}$, fat intake consists of total fat was $27.01 \pm 6.68 \%$ calorie, SFA was $24,7510.07 \%$ calorie, MUFA was $10.24 \pm 5.41 \%$ calorie, and PUFA was $7.35 \pm 3.54 \%$ calorie. Average of plasma SOD activity was $5.85 \pm 3.41 \mathrm{u} / \mathrm{mL}$. There were no correlations between fat intake (total fat, SFA, MUFA, and PUFA) with telomere length ( $p>0.05$ ), but there was a significant positive correlation between plasma SOD enzyme activity with telomere length ( $\mathrm{r}=-0.202, \mathrm{p}=0.037)$.

Conclusion: Fat intake within normal limits does not correlate with telomere length, and plasma SOD activity is a risk factor for telomere shortening in ethnic Minangkabau men.

Keywords: Telomere length, Fat, Intake, Total fat, Superoxide dismutase activity.

(c) 2019 The Authors. Published by Innovare Academic Sciences Pvt Ltd. This is an open access article under the CC BY license (http://creativecommons. org/licenses/by/4. 0/) DOI: http://dx.doi.org/10.22159/ajpcr.2019.v12i2.29594

\section{INTRODUCTION}

Non-communicable diseases (NCD) are the main cause of death globally and nationally today [1]. Based on the WHO data (2014), early mortality due to NCD in 30-70 years old increased from $23.1 \%$ in 2010 to $23.3 \%$ in 2012. NCDs also increased in Indonesia. Basic Health Research Results (2007) show that infectious diseases cause $28.1 \%$ of deaths [1,2]

The increase in NCD is related to the aging process that occurs at the organ level which causes a decrease in the metabolic function of the organ. The aging process which is very fast and the accumulation of cellular damage will cause cell damage which has an impact on organ malfunctions, causing an increased risk of chronic illness and premature death $[3,4]$.

Telomere length can be used as a biomarker for aging and survival of cells. Progressive telomere shortening causes aging, apoptosis, or oncogenic transformation of somatic cells [5]. Telomere shortening occurs with age. The average telomere shortening is not constant and varies for each person [3].

Telomere shortening is influenced by genetic and lifestyle factors. Some lifestyle factors such as eating patterns play an important role in the telomere shortening process. A high-fat diet with fewer fruits and vegetables as a source of antioxidants can cause obesity, which will increase the release of reactive oxygen species (ROS) which is responsible for oxidative stress. Very fast telomere shortening is strongly related to the presence of inflammatory reactions and oxidative stress in the body [6].

The results of the study Song et al., 2013, state that there is a direct relationship between the amount and type of fat intake and fat-rich foods to telomere length. People who consume high amounts of saturated fatty acids (SFA) have shorter telomere length than people who consume low amounts of SFA [7]. High consumption of animal fat (meat) has an inverse relationship with telomere length $[3,8]$. A highfat diet can increase inflammation and the production of ROS so as to increase oxidative stress in the body. Oxidative stress in the long term is the most important role contributing to the acceleration of telomere shortening [6,8-10].

Telomere shortening is determined by the balance of ROS and antioxidants in the body [11]. Antioxidants are protective agents that deactivate ROS so that it can significantly prevent oxidative stress. Superoxide dismutase (SOD) is a major antioxidant in blood vessels and has a high affinity for the surface of the vascular endothelium, so there is a high amount of blood vessels. SOD activity also presents the body's intracellular antioxidant abilities. The imbalance between superoxide anion production (02-) and the activity of the enzyme SOD can cause the formation of new radical compounds. Makino's research (2011) proved that in mice with SOD deficiency had higher levels of oxidative stress and lower activity of telomerase enzymes than mice with normal levels of SOD $[12,13]$.

Minangkabau ethnic men are people in West Sumatra who have a diet high in saturated fat and low in vegetables and fruits [13]. Consumption of coconut oil and high coconut milk is the main source of high levels of SFA in the blood. Sulastri et al. reported that the saturated fat intake of the Minangkabau ethnic community was higher than the recommended adequacy rate [14]. This study aimed to determine the relationship between fat intake and plasma SOD enzyme activity with telomere lengths of Minangkabau ethnic men. 


\section{METHODS}

This study was an analytic observational study with a cross-sectional study design. The study was conducted on 107 ethnic Minangkabau men, who worked as civil servants at subdistrict offices throughout Padang City. Data consisted of fat intake (total fat, SFA, and monounSFA (polyunsaturated fatty acid [PUFA]), not fatty acids single saturated (monounsaturated fatty acid [MUFA]) was obtained through interviews using the semi-quantitative food frequency questionnaire, while plasma SOD activity was examined by calorimetric (quantitative SOD enzyme activity in plasma serum) using bioassay systems SOD kit (ESOD-100). Telomere length was measured using real-time PCR according to Challaghan and French (2011) methods [15]. The standard oligomer used for Telomere Length Check is (TTAGGG)n, and primary PCR were CAGCAAGTGGGAAGGTGTAATCC and CCCATTCTATCAACCGGGTACAA

Data are processed using a computer program and displayed in the form of a description of mean values and standard deviations, to see the relationship between variables conducted Pearson correlation test and linear regression to see the predictions of independent variables on the dependent variable. This study was approved by the Ethical Committee of Medical Faculty, Andalas University, with registration number 051/KEP/FK/2016.

\section{RESULTS}

Padang City is the capital of West Sumatra Province with an area of $694.96 \mathrm{~km}^{2}$ and has a population of 784,740 people with a population density of about 1129 people $/ \mathrm{km}^{2}$. The city consists of 11 districts and 104 subdistrics. The study was conducted in 11 subdistricts in Padang City. In each subdistrict, population screening was carried out by taking into account inclusion and exclusion criteria. The total subject of the study consisted of 130 men but who meet the inclusion and exclusion criteria are 107 men.

In Table 1, we can see the average length of the telomere, fat intake (total fat, SFA, MUFA, and PUFA), and plasma SOD enzyme activities.

In Table 1, it is known that the average length of telomere respondent is $584.59 \pm 305.92 \mathrm{bp}$, the total fat intake of respondents is $27.01 \pm 6.68 \%$ calories, the intake of SFA is $24.75 \pm 10.70 \%$ calories, MUFA intake was $10.24 \pm 5.41 \%$ calories, intake of PUFA is $7.35 \pm 3.54 \%$ calories, and plasma SOD enzyme activity is $5.93 \pm 0.81$ units $/ \mathrm{ml}$.

Correlation of total fat intake, MUFA, SFA, and PUFA with telomere length of Minangkabau ethnic men can be seen in the picture below.

Fig. 1 shows that there was no significant correlation between total fat intake and telomere length $(p=0.422, r=0.098) . R^{2}=0.01$ indicates that the effect of total fat intake on telomere length is $1.0 \%$.

Correlation analysis in Fig. 2 shows that there is no significant correlation between saturated fat intake (SFA) and telomere length $(r=0.004, p=0.966) . R^{2}=0.014$ shows that the effect of SFA intake on telomere length is $1.4 \%$.

In Fig. 3, we can see that there is no significant positive correlation between MUFA intake and telomere length ( $\mathrm{r}=0.014, \mathrm{p}=0.885) . \mathrm{R}^{2}=0.001$ shows that the effect of MUFA intake on telomere length is $0.1 \%$.
Fig. 4 shows a non-significant positive correlation between PUFA intake and telomere length $(r=0.029, p=0.768,) . R^{2}=0.002$ shows that the effect of PUFA intake on telomere length is $0.2 \%$.

Correlation analysis in Fig. 5 shows a positive significant correlation between SOD enzyme activity and telomere length. The correlation of plasmaSOD enzyme activity with telomere length has a low relationship level and a positive pattern which means that the higher the plasma SOD enzyme activity, telomere length is longer $(p=0.037, r=0.202)$. $\mathrm{R}^{2}=0.094$ shows that the effect of plasma SOD activity on telomere length is $9.4 \%$.

The results of plasma SOD enzyme activity regression test with telomere length of ethnic Minangkabau male can be shown in Table 2 .

Plasma SOD enzyme activity has a significant positive correlation with telomere length and a regression test was performed to see the

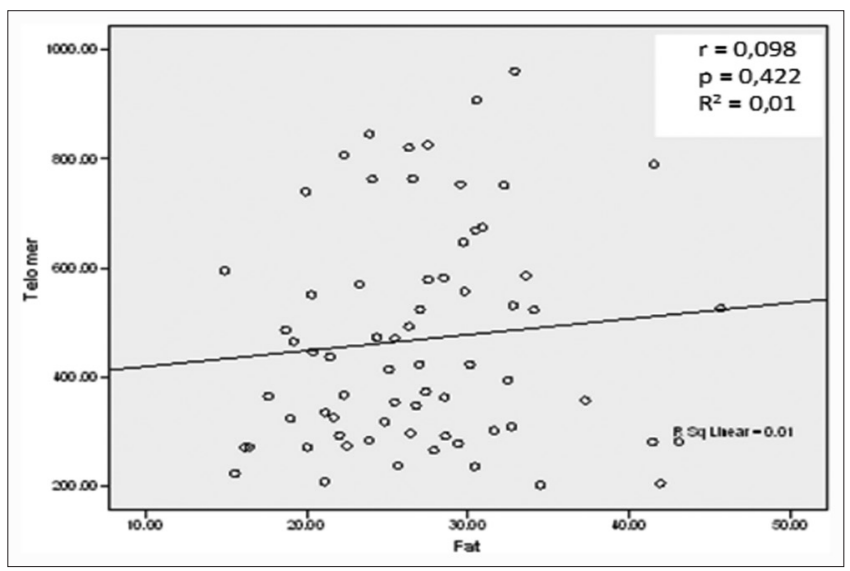

Fig. 1: Correlation between total fat intake and telomere length of Minangkabau ethnic men

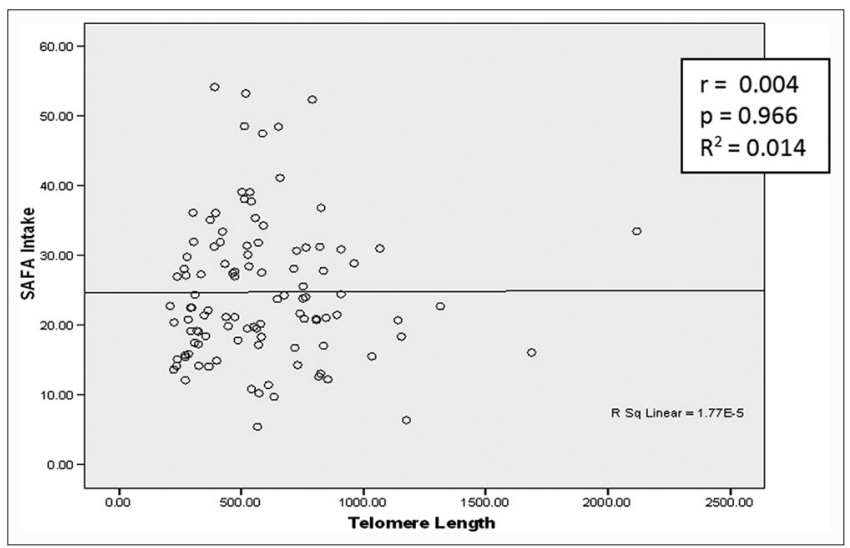

Fig. 2: Correlation between saturated fatty acid intake and telomere length of Minangkabau ethnic men

Table 1: Average length of telomere, fat intake (total fat, SFA, MUFA, and PUFA), and plasma SOD enzyme activities for Minangkabau ethnic men

\begin{tabular}{|c|c|c|c|}
\hline Variable & Average $\pm S D$ & Min. & Max. \\
\hline Telomere (bp) & $584.59 \pm 305.92$ & 208.00 & 2117.00 \\
\hline Total fat intake (\% calorie) & $27.01 \pm 6.68$ & 12.67 & 22.80 \\
\hline SFA intake ( $\%$ calorie) & $24.75 \pm 10.70$ & 5.43 & 54.16 \\
\hline MUFA intake (\% calorie) & $10.24 \pm 5.41$ & 2.68 & 29.16 \\
\hline PUFA intake ( $\%$ calorie) & $7.35 \pm 3.54$ & 2.07 & 18.54 \\
\hline Plasma SOD enzyme activities (unit/ml) & $5.93 \pm 0.81$ & 3.42 & 7.06 \\
\hline
\end{tabular}

SFA: Saturated fatty acids, MUFA: Monounsaturated fatty acid, PUFA: Polyunsaturated fatty acid, SOD: Superoxide dismutase, SD: Standard deviation 
similarity between plasma SOD enzyme activity and telomere length. Regression equations that can be made based on Table 2 are as follows: $\mathrm{Y}=23.431 \pm 75.079 \mathrm{X}$ or telomere length $=23.431 \pm 75.079$ (plasma SOD

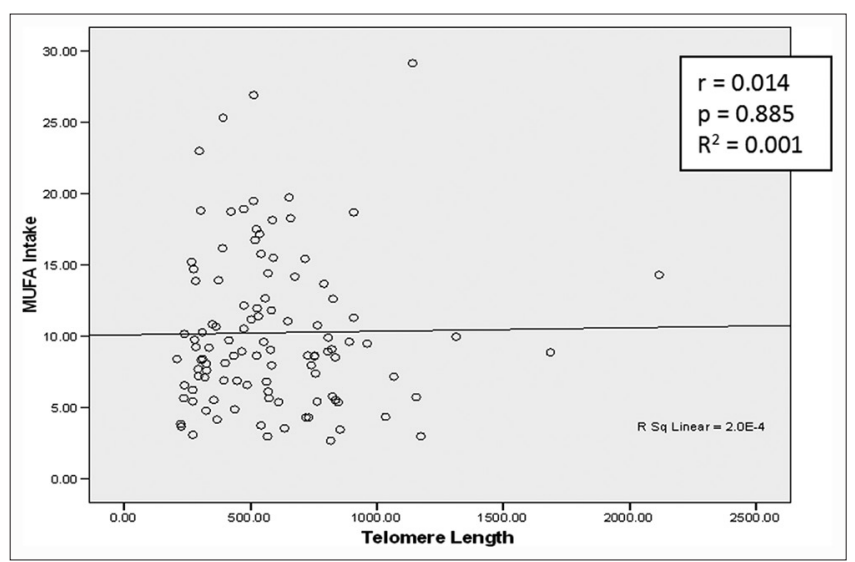

Fig. 3: Correlation between monounsaturated fatty acid intakes with telomere length of Minangkabau ethnic men

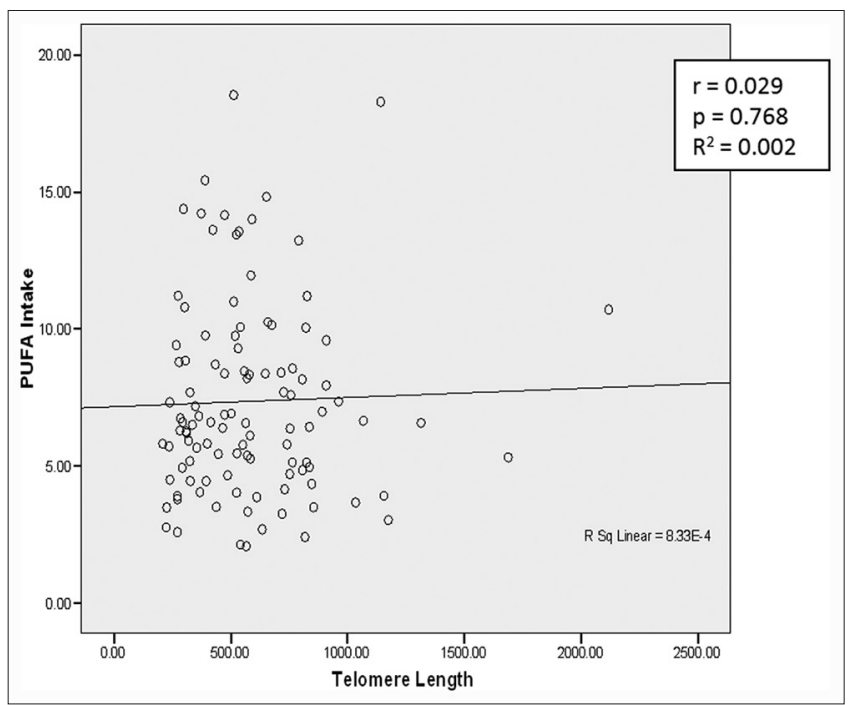

Fig. 4: Correlation between polyunsaturated fatty acid intakes with telomere length of Minangkabau ethnicity men

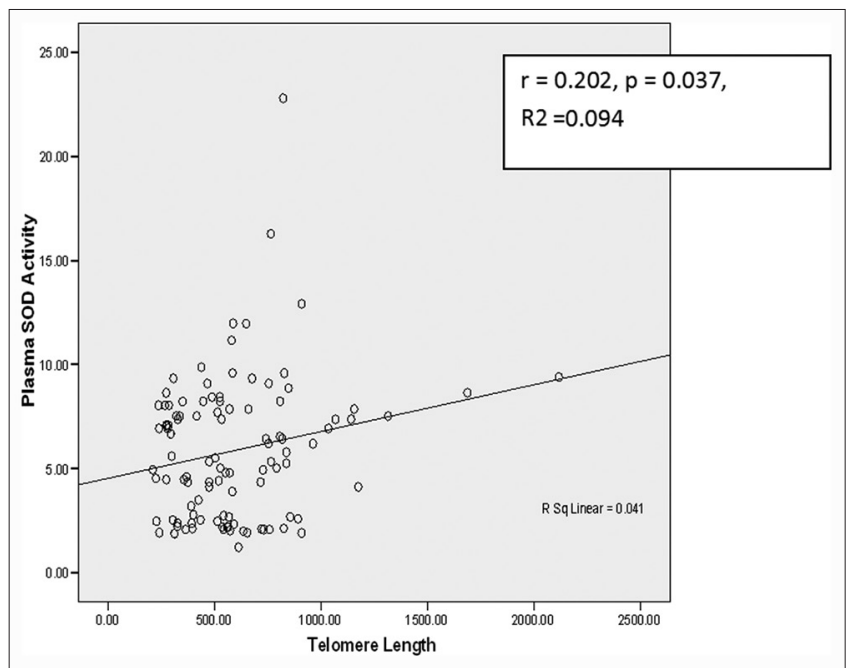

Fig. 5: Correlation between plasma superoxide dismutase enzyme activities with telomere length of Minangkabau ethnic men enzyme activity). Every increase of 1 unit/ML plasma SOD enzyme activity will decrease $75.079 \mathrm{bp}$ telomere length.

\section{DISCUSSION}

Telomere length

Telomere is the structures of DNA proteins that do not contain genes (non-coding) which are located at the end of the chromosome and experience shortening with each cycle of cell division $[11,16]$. In this study, the average of telomere length was $584.59 \pm 305.92 \mathrm{bp}$. The same results were reported by Tucker et al. (2018), in the US adult men, aged 46.5 years, having telomere length was 5826 bp [17]. The telomere length in this study was shorter than population men of Asklepios, with an average age of $46.1 \pm 5.9$ years, which telomere length was $7.78 \pm 0.71 \mathrm{kbp}(7780 \pm 710 \mathrm{bp})$. Different results were also reported by Kushner et al., the telomere length of 48-year-old healthy men was $10,565 \pm 572$ bp $[18,19]$.

Telomere length is influenced by several factors, namely genetic, race, gender, age, and lifestyle factors. Some lifestyle factors that can affect telomere length are smoking habits, physical activity, diet, and obesity $[20,21]$. Women have a longer telomere than men because the influence of estrogen levels [22]. Geographic factors such as pollution and UV rays of the sun also play a role in telomere erosion [21]. The interaction between genetic factors, lifestyle, and the environment tends to increase the occurrence of oxidative stress and inflammatory processes in the body and modulate telomere shortening acceleration, biological aging that affects the development risk of chronic disease $[10,23]$.

The antioxidant defense in the body also plays a role in determining telomere length. Low antioxidant capacity in the body decreases the ability to reduce the effects of free radicals which can cause DNA damage and telomere shortening acceleration [20]. The balance between oxidative damage and antioxidant defense capacity as a determinant of telomere length can also be critically affected by eating habits. Some micronutrients in food are antioxidants so that they provide protection against oxidative stress and DNA maintenance [20]. The difference between these results and several other studies may be due to differences in race, lifestyle, and environment.

\section{Plasma SOD enzyme activity and telomere length}

SOD is an endogenous antioxidant that functions in the body's defense system against ROS. This enzyme plays a role in catalyzing the conversion reaction of superoxide radical (02-) to hydrogen peroxide and molecular oxygen and is the only enzyme that has the ability to eliminate the toxic effects of superoxide radicals [24].

In this study, the average SOD enzyme activity was 5.93 unit $/ \mathrm{mL}$ and there was a significant positive correlation between plasma SOD enzyme activity and telomere length. Plasma SOD enzyme activity was lower than the research conducted by Prastuty et al., in 2012, on patients with type 2 diabetes mellitus (T2DM) in Yogyakarta [25] but higher than the results of Kristina et al. (2016) research on patients with T2DM and normal people in Jakarta [26]. This difference in results is thought to be due to differences in the study population, where this study was conducted in normal communities in the city of Padang, while two other studies were carried out on patients with T2DM in Jakarta and Yogyakarta. Differences in diet, lifestyle, culture, and geography can also affect plasma SOD enzyme activity [25,27].

SOD enzyme as a biomolecule can be damaged if the condition of free radicals in the body increases and the enzymatic activity will significantly decrease. The damage that occurs in the SOD enzyme depends on the dose and length of exposure to free radicals in the body $[23,26]$. In normal circumstances, there is the right balance between free radicals and antioxidants. However, this balance can shift when free radical production increases. Oxidative stress results from an imbalance between free radical production and a radical dampening system, either increasing free radical production or decreasing the antioxidant activity of defense or both [16]. 
Table 2: Plasma SOD enzyme activity regression test with telomere length of Minangkabau ethnic men

\begin{tabular}{|c|c|c|c|c|c|}
\hline \multirow[t]{2}{*}{ Model } & \multicolumn{2}{|c|}{ Unstandardized coefficients } & \multirow{2}{*}{$\begin{array}{l}\text { Standardized } \\
\text { coefficients } \\
\text { Beta }\end{array}$} & \multirow{2}{*}{$\begin{array}{l}\mathrm{t} \\
\mathrm{B} \\
\end{array}$} & \multirow{2}{*}{$\begin{array}{l}\text { Sig. } \\
\text { Standard error }\end{array}$} \\
\hline & B & Standard error & & & \\
\hline \multicolumn{6}{|l|}{1} \\
\hline Constant & 23.431 & 170.906 & & 0.137 & 0.891 \\
\hline Plasma SOD activity & 75.079 & 28.539 & 0.306 & 2.631 & 0.011 \\
\hline
\end{tabular}

\section{Fat intake and telomere length}

Fat intake consists of total fat intake, SFA, MUFA, and PUFA. In this study, the average fat intake is still within the recommended limits. Several studies of Minangkabau ethnic groups show similar results, namely Liputo et al. (2001) reported the Minangkabau ethnic consumption of $10.6-21.7 \%$ of total energy with $18 \%$ administrative law judge (ALJ) [17]. The results of this study were lower than that of Hatma's (2001) study, fat consumption of Minangkabau ethnic group was 30.1\% of total energy with ALJ 35.3\% and Purwantyastuti (2000) reported that fat intake in Minangkabau ethnic groups in Jakarta was 36\% with ALJ 22\% [18,19]. While Sulastri et al. reported that overall fat intake in the Minangkabau ethnic group is still within the recommended limits, but when viewed from the composition of the type of fatty acids, ALJ intake exceeds the recommended number [14]

In this study, there was no correlation between fat intake and telomere length. This is probably due to fat intake (total fat, SFA, MUFA, and PUFA) still within normal limits so that it is not enough to cause oxidative stress in the body. The same results were also reported by Song et al. [7]. Food intake containing high SFA can increase the release of ROS and proinflammatory cytokines so as to increase oxidative stress levels in the body, so the plasma MDA will be high. Eating habits by consuming SFA that exceed standard requirements, in the long run, can increase the formation of ROS in various tissues. Increased consumption of saturated fats (such as palmitic acid) can cause an increase in ROS through the mechanism of NADPH oxidase. Cytokine-induced NADPH oxidase in inflammatory processes or disorders of the mitochondrial electron transport chain that causes an increase in oxidative stress [19,20]. In this study, total fat intake and SFA were still within the recommended limits.

Nutrition affects telomere length through various mechanisms that reflect its role in cellular function. The results of Ornish's study (2008) state that consumption of low fat ( $10 \%$ of calories from fat), foods with a plant-based diet are concentrated in vegetables, fruits, nuts, unrefined grains, as well as minimizing the intake of refined carbohydrates can maintain the length of telomere and increase life expectancy in prostate cancer patients [21]. Oxidative stress caused by a high-fat diet and lack of vegetables can cause DNA damage, and therefore, it is possible to accelerate telomere shortening so that it may speed up the unnecessary aging process [28]. Then, high-fat diet changes the expression of neuropeptides in the medial hypothalamus which is responsible for the regulation of feeding and energy metabolism [29].

\section{CONCLUSION}

Minangkabau men have significantly shorter telomeres than those found in other population. There was no significant relationship between fat intakes with telomere and there was positive significant correlation between plasma SOD enzyme activities with telomere length.

\section{Significance statement}

This study demonstrates that fat intake within normal limits does not correlate with telomere length, and plasma SOD enzyme activity is a risk factor for telomere shortening in ethnic Minangkabau men.

\section{ACKNOWLEDGMENT}

We would like to thank the Medical Faculty of Andalas University for funding this research project (Grant No 33/UN.16/HKRGB/
LPPM/2016) and special thanks to all respondents who participated in this research

\section{AUTHORS' CONTRIBUTION}

Afriwardi, DelmiSulastri, Yuniar Lestari, Desmawati, and Prima Minerva have contribution in this publication. Sulastri who is the corresponding author, chairman of the study, a manuscript drafter. Afriwardi is the main author who has an idea to write about this, manuscript drafter, and helped to correct the manuscript. Yuniar Lestari, Desmawati, and Prima Minerva are members of the researcher team, manuscript drafter, and correct the manuscript.

\section{CONFLICTS OF INTEREST}

The authors declare that they have no conflicts of interest in this study.

\section{REFERENCES}

1. Minister of Health RoI. Overview of Non-Communicable Diseases in Indonesia 2009-2010. Jakarta: Data and Information Center; 2012.

2. WHO Global Global Status Report on Non Communicable Disease Data by Country; 2014. Available from: http://www.apps.who.int/gho/ data/node.main.688?lang=en. [Last cited on 2016 feb 14].

3. Lee M, Martin H, Firpo MA, Demerath EW. Inverse association between adiposity and telomere length: The fels longitudinal study. Am J Hum Biol 2011;23:100-6.

4. Minister of Health RoI. Plan for Operational Health Promotion in Control of Non-Communicable Diseases. Jakarta: Health Promotion Center; 2010.

5. Shammas MA. Telomeres, lifestyle, cancer, and aging. Curr Opin Clin Nutr Metab Care 2011;14:28-34.

6. Boccardi V, Esposito A, Rizzo MR, Marfella R, Barbieri M, Paolisso G, et al. Mediterranean diet, telomere maintenance and health status among elderly. PLoS One 2013;8:e62781.

7. Song Z, von Figura G, Liu Y, Kraus JM, Torrice C, Dillon P, et al. Lifestyle impacts on the aging-associated expression of biomarkers of DNA damage and telomere dysfunction in human blood. Aging Cell 2010;9:607-15.

8. Susantiningsih T. Obesitas dan stres oksidatif. J Kedokteran 2013;5:89-93.

9. Tiainen AM, Männistö S, Blomstedt PA, Moltchanova E, Perälä MM, Kaartinen NE, et al. Leukocyte telomere length and its relation to food and nutrient intake in an elderly population. Eur J Clin Nutr 2012;66:1290-4.

10. Bollapragada MK, Shantaram M, Kumar S. Obesity: Development, epidemiology, factor affecting, quantity, health hazards, amanagement and natural treatment-a review. Int J Pharm Pharm Sci 2017;9:12-26.

11. Muchtadi D. Gizi Anti Penuaan Dini. Bandung: Penerbit Alfabeta; 2009

12. von Zglinicki T. Oxidative stress shortens telomeres. Trends Biochem Sci 2002;27:339-44

13. Makino N, Maeda T, Oyama J, Sasaki M, Higuchi Y, Mimori K, et al. Antioxidant therapy attenuates myocardial telomerase activity reduction in superoxide dismutase-deficient mice. J Mol Cell Cardiol 2011;50:670-7

14. Sulastri D, Rahayuningsih S, Purwantyastuti D. Pola asupan lemak, serat, dan antioksidan, serta hubungannya dengan profil lipid pada lakilaki etnik minangkabau. Majalah Kedokteran Indones 2005;55:61-6.

15. O'Callaghan NJ, Fenech M. A quantitative PCR method for measuring absolute telomere length. Biol Proced Online 2011;13:3.

16. Guney Y, Bilgihan A, Ciftci TU, Cimen F, Coskun O. Serum malondialdehyde levels and superoxide dismutase activities in 
pulmonary ankara universitesi dikimevi saglik hizmetleri. Meslek Yüksekokulu Derg 2004;6:33-8.

17. Lipoeto NI. Kadar Asam Lemak Omega Tigadan Konsumsi Produk Kelapa pada Etnik Minangkabau di Sumatera Barat. Semarang: Proceeding Kongres Nasional PDGMI; 2016.

18. Hatma RD. Lipid profiles among diverse ethnic groups in Indonesia. Acta Med Indones 2011;43:4-11.

19. Purwantyastuti P. Relation of Lipid Peroxides to Food Habit, Selected Coronary Heart Disease Risk Factors and Vitamin E Supplementation in the Elderly. Jakarta: Disertasi University of Indonesia; 2000.

20. Kasielski M, Eusebio MO, Pietruczuk M, Nowak D. The relationship between peripheral blood mononuclear cells telomere length and dietunexpected effect of red meat. Nutr J 2016;15:68.

21. Ornish D, Lin J, Chan JM, Epel E, Kemp C, Weidner G, et al. Effect of comprehensive lifestyle changes on telomerase activity and telomere length in men with biopsy-proven low-risk prostate cancer: 5-year follow-up of a descriptive pilot study. Lancet Oncol 2013;14:1112-20.

22. Yusrawati Y, Sulastri D, Desmawati D. The correlation between estradiol levels with telomere length based on history of using hormonal contraceptive in premenopausal women Asian J Pharm Clin Res 2018;11:336-9.
23. Shao HW. Effect of superoxide dismutase and malondialdehyde metabolic changes on carcinogenesis of gastric carcinoma. World $\mathrm{J}$ Gastroenterol 2005;11:4305-10.

24. Wang Y, Zhou WD, Yang Y, Ma L, Zhao Y, Bai Z, et al. Telomeres are elongated in rats exposed to moderate altitude. J Physiol Anthropol 2014;33:19.

25. Prastuti B, Sunarti S. Pengendalian SOD dan NO pada DMT2 dengan emping garut sebagai makanan selingan. J Gizi Klin Indones 2012;8:118-25

26. Kristina H, Sartono N, Rusdi R. Kadar peroksida lipid dan aktivitas superoksida dismutase serum darah pada penderita DMT2. Bioma 2012; $12: 32-40$

27. Khairunisa S, Subchan P, Himbawami M. Uji korelasi antara nilai aktivitas superoxide dismutase dalam eristrosit dengan derajat keparahan akne vulgaris pada wanita. MDVI 2011;38:2-5

28. Eszy MS, Sastri S, Masri M. Pengaruh pemberian diet tinggi minyak sawit terhadap kadar malondialdehid darahtikus wistar. J Kesehatan Andalas 2014;3:409-14.

29. Sherzay N, Chitakar E. Epigenetic: Effect of enviromental factors on human genome. Int J Pharm Pharm Sci 2016;8:1-6. 